early creeds; their discussions are full of suggestion. Whether they make good their position or not, they do splendid service in fixing our gaze on the person and work of the Redeemer. Dr. Bruce's work on The Humiliation of Christ is the best English exposition of their teaching (Lect. IV.).

The Germans have set a noble example to other Churches of devotion to the higher walks of sacred learning, and the example has not been without influcnce. In some quarters there is a strange prejudice, not merely against the higher theology, but against theology altogether. We say "strange," because if theology is to our knowledge of spiritual things what science is to our knowledge of the physical world and philosophy to our knowledge of the mental world, we might as well discard science and philosophy. The very fact that heretics always denounce theology as the root of all the evils of the Church, may perhaps suggest that it renders no mean service in exposing error. We can no more help being theologians than we can help being philosophers. Those who denounce systems of metaphysics and dogma have systems of their own, as we have already seen. The only question for us is whether we will have a true theology or not. A Church that should discourage or neglect theological study, or limit its aims to the satisfaction of practical needs, would lose hold on the highest intelligence of the day. Plato and Bacon, Newton and Butler are not "popular" teachers, as Spenser and Milton, Wordsworth and Browning are scarcely "popular" poets, but they make teachers and poets. The few who in every Church devote themselves to the work of research do incalculable good in keeping up a high standard of knowledge. Roman Catholic, Anglican, I'resbyterian, Congregational-all recognise this fact. Of scholars, as well as of pastors and evangelists, may "the bright succession run through the last courses of the sun."

\title{
In Memoriam FENTON JOHN ANTHONY HORT, D.D., LL.D., D.C.L.
}

\author{
By 'The Rey. Professok W. Milligin, D.I), Aberdeen.
}

Nothing but the request of one of his dearest and most universally honoured friends could tempt me to break, by any words of mine, the deep silence that now reigns around the grave of my beloved friend, Dr. Hort, in the Mill Road Cemetery, Cambridge. I)r. Hort was one who never sought the applause of men; and had he expressed any wish as to the manner in which his memory should be regarded by the world, he would have simply said, let me rest in peace. He would have clung to the thought that he would be remembered with tender and loving affection by a few, and that in their hearts he would hold a place which could never be lost either through length of time or change of circumstances. He loved his friends with an intensity of affection of which only natures as true and simple as his are capable, and it was in their answer of love to love that he rejoiced. Not that he despised the world, or that there was the slightest trace of cynicism in the feelings with which he regarded it. $\mathrm{He}$ thought of it with respect, and confidence, and hope. But his own heart needed more than it was in the power of the world to give, and his own wish would have been only to live on in the hearts of those nearest and dearest to him, and of those friends towards whom his affection brimmed over like a too full cup, and to whom he had knitted himself, as they were knitted to him, by bands of steel. I feel also that I cannot speak of him as he ought to be spoken of, for no words will convey to men in general a correct impression of what he was, or can even contain the meaning which those who were most intimate with him would desire them to bear. Yet it is right that something should be said of him whom we have lost, partly perhaps because the utterance of the mouth gives the heart relief, mainly because the recalling what he was may stimulate ourselves and others to try to be more like him.

The facts of his life are few, and may be told in a single sentence or two. He was born at Dublin 
in 1828 , so that when he died on the 3 oth November last he was in the sixty-fourth year of his age, but still in the full maturity of his powers. Of his early training and of his distinguished career at Cambridge it is not necessary to say much. The particulars will be found in the beautiful tribute to his memory paid, in the Cambridge Reviez of the cighth of this month, by one who was once his pupil, and more recently his colleague in a professorship of the Divinity School of Cambridge, Professor Ryle, son of the well-known Dr. Ryle, now Bishop of Liverpool. Let it be enough to say that he was educated at Rugby under Arnold and Tait, and that at College he was a bosom friend of such men as Lightfoot, Westcott, and the present Archbishop of Canterbury. In ${ }^{2} S_{52}$ he was made a Fellow of Trinity. In ${ } S_{57}$ he was appointed to the College living of St. Ippolyts, near the Hitchin Station of the London and NorthWestern Railway, and in the same year he married. In 1872 he was made Inivinity Lecturer of Emmanuel College; in ${ }_{1} 88$ Hulsean Professor; and in 1887 Jady Margaret's Professor of Divinity in the University. In this last post he died, and in the chapel of his own College of Emmanuel the sad ceremonial preceding his funeral took place. Within that College he had studied and taught. It had been the first to open to him the wide sphere of usefulness which he afterwards occupied with so much good to others and honour to himself; and no spot of earth could have been more fitly chosen than its chapel for the gathering of the mourners who, in bitter grief, but not the less with grateful recollections and triumphant hopes, accompanied his body to the grave.

Although the active life of Dr. Hort may in the minds of many be associated mainly with his work in the New Testament Revision Company, of which he was made a member at its formation in 1870 , it must not for a moment be imagined that it was confined to the ten years during which that Company pursued its labours. He had been from the first, and all along, a student of the most earnest, thorough, and devoted kind. He had indeed been prepared, as few members of the Company had been, by a long course of toil in biblical study generally, and more especially in the study of the New Testament text, for the part which he took in the work of revision. People are apt to imagine that translation was the main work of the Company, but they are mistaken in thinking so. By much its hardest and most difficult task, that, too, upon which the opinions of its members most differed, was the determination of the text. For twenty years before the Company was called into existence, and for the sake of the subject itself, Dr. Hort had devoted himself, along with the present Bishop of Durham, to that then almost unknown, to that apparently uninteresting but really fascinating field. It is not too much to say that from the labours of Westcott and Hort, not jet fully appreciated, a new era in the textual criticism of the New Testament may date its beginning. Nor was it simply the extensive and varied learning of the two scholars which produced this result. It was the principles upon which they proceeded, the grounds of judgment, entitled to be called scientific in the strictest sense of the term, which they laid down with the most exact precision, and followed out with the most unfaltering faithfulness. From the days of Mill and Bentley, textual criticism had left England for the Continent, where it flourished under the great critics, who bring us down to a comparatively recent date. Now, under Westcott and Hort, it returned to its former home; it deserted the Continent, and under these two men (preceded, however, in publication by Tregelles) it established itself in such a way that Germany, France, Switzerland, and America, instead of giving as they once did lessons to the world, are glad to learn them in an English school. Those who have studied the volume of Introduction, published in ISSI, to Westcott and Hort's Greek Text of the Nere Testament, or who have made themselves acquainted with its influence in other lands, will acknowledge the truth of what has now been said. The whole contents of that goodly volume were written by Dr. Hort.

I have probably dwelt too long on this, although it would not have been easy to avoid it. Let us return to the Revision Company and look at Hort as he sits with many books of reference before, and some of the most bulky on a table behind him, at the south-west corner of the long table which occupies so much of the space of the Jerusalem Chamber. There are many men there of an ability and learning which might make the best scholar of the land hesitate to argue a point against them. but this minister of St. Ippolyts, for he was not a Professor till the Company was well on in its labours, has special knowledge, and he uses it with 
the self-possession, the boldness, the freedom, and y'et withal with the simplicity and humility which marked all his presentations of what he believed to be the truth. No wonder that, backed as he was by Westcott and Lightfoot, he exercised an almost imperial sway in the formation of the text which the Company adopted. In addition, he brought also to the work of translation services of the most valuable kind, and lent no mean aid to the solution of many a difficult task of rendering into English such parts of the Greek text as, with all their unspeakably valuable services, former translators had failed to understand or express.

It was the same in everything. Whatever Dr. Hort did was thorough. Nothing would satisfy him but to probe to the bottom every difficulty that met him. And in this no doubt lies the explanation of the fact that, with the exception of the volume mentioned above, and of a smaller volume containing his two most characteristic and valuable Dissertations on the true reading of John i. I 8, and on the Constantinopolitan Creed and other Eastern Creeds of the fourth century, he has left, so far as I know, nothing but scattered papers in one or two journals behind him. He was almost too sensitive, too fearful of not doing sufficient justice to every point he had to deal with. It is possible that short essays upon various important questions may be found among his papers. Not one of them should be lost.

Let me turn once more, in a few parting sentences, to the man, to his noble, pure, loving nature, full of a childlike joy in his friends, and yet so humble and simple that he never thought how he was communicating happiness to them. $\mathrm{He}$ thought only that they were communicating happiness to him. And, as on a spring or summer day, he would, in that garden, or under those trees, behind his house in Cambridge, hasten from one spot to another to try and bring some little addi. tional comfort to his guests, it was sometimes almost painful to be so served by one to whom the guests could not help feeling it would have been far more fitting in them to render service. Professor
Rylc has given a fine picture of him in his Library, and $I$ think it a pity that the numerous readers of The Expository Times should not see it: "as he starts up from his chair where he is sitting, before his papers and at his books, and comes out behind the great revolving bookcase, with the cheery welcome and the warm clasp of the hand, you see him before you; the wonderful bluc eye piercing keenly beneath the pent-house of bushy brow, the worn, emaciated chcek, the noble forehead; you hear the bright glee of his merriment, you catch the tremendous energy of his purpose in all he says, his noble loyalty to his friends, the noble scorn of meanness. These are burnt upon the memory." Yes, he would start up; he would shake you by the hand as if it needed not the hand only, but the whole body to give cxpression to his feelings. And then, into any field you liked, whether of Theology, or Philosophy, or even (in some departments) of Natural Science, eager to tell his thoughts, to hear the thoughts of others, but above all things to be honest and true. He was a splendid student and a most loving man. Happy they who have known such men, for it is a perpetual joy to remember them, even while it is no less a pain to think that on earth we shall hear their voice no more. But we may cherish their memory. We may walk with them in thought. We may strengthen ourselves by the recollection of all that they were in public or private life, in hours of work or hours of ease. When we remember Dr. Hort, too, we may think of him as triumphing in the power of the spirit over a weakly frame; so that if his life was a constant victory, that victory was preceded by constant struggle. The struggle is over now. On the morning of the day on which he died, he had said that he thought he should like a long sleep. $\mathrm{He}$ fell asleep, and the end came while he slept. It was a suitable if a touching end. He had worked his work, and then he slept. Nay, he sleeps now a calmer, more peaceful sleep than ever he knew on earth, to be followed by a more glorious awaking. 